\title{
DISCLOSURE QUALITY ON THE POLISH ALTERNATIVE INVESTMENT MARKET NEWCONNECT
}

\author{
Dominika Fijałkowska, Michał Muszyński, Marek Pauka \\ Faculty of Economic Sciences, Wroclaw University of Economics, Poland
}

\begin{abstract}
:
The scope of our research was to examine the relationship between disclosure quality and firms' characteristics of the issuers listed on the Polish alternative investment market NewConnect. On the basis of the sample of 200 issuers, we demonstrated that disclosure quality is only significantly and positively correlated with the firm's size and provided no evidence for relation among disclosure quality, debt ratio and issuers' listed history. Our findings support the low level of investors' relation. Issuers are not willing to help the investors to understand the reasons for such performance and refuse to give a complex picture of companies' goals, strategic success factors, investments' plan and risk management particulars. These results are consistent with our observations and we indicate the low level of issuers' corporate governance, which is characteristic for the first stage of market development, as the main reason: issuers are still learning disclosing obligations, investors adopt passive behaviour and financial investors have low significance as market participants.
\end{abstract}

\section{Key words:}

voluntary disclosure quality, annual report,

firm performance,

alternative investment market.

Project was financed with fund support of National Science Center based on decision number DEC-2011/01/D/HS4/05926.

\section{INTRODUCTION}

The disclosure quality of companies listed on the stock exchanges is the crucial issue from both a theoretical and empirical perspective. Market regulators and authorities claim that disclosure quality and corporate governance influence investors' protection and capital market efficiency inseparably (Blue Ribbon Report 2000, Cadbury Report 1992, OECD 1999, Allegrini, Greco 2011). The quality of disclosure can be defined as a number of non-mandatory information (financial and non - financial), which issuers voluntary publish in annual and quarterly reports (among others: Botosan 1997, Botosan and Plumlee 2002, Eng and Mak 2003). The additional information disclosed in mandatory reports can reduce information asymmetry and agency costs (Verrecchia 2001).

Glosten and Milgrom (1985) develop a model, which discovers the relation between disclosure quality (DQ) of companies and information asymmetry. According to their model information asymmetry decreases together with the increase of DQ (Glosten i Milgrom, 1985). Welker (1995), Lang and Lundholm (1993), Verrecchia (1983, 1990), Barry and Brown (1984, 1985), Merton (1987) Kim and Verrecchia (1994) and others empirically confirm assumptions of Glosten and Milgrom model suggesting that companies which publish better quality disclosure have higher analysts' following, what reduces negative selection, positively influences the quality of analyst earnings forecasts and their dispersion (Lang, Lundholm 1993, 1996). Additionally, the reduction of information asymmetry between directors and outside investors increases stock liquidity and institutional investors' interest (Verrecchia 1983, 1990, Barry, Brown 1984, 1985, Merton 1987, Kim, Verrecchia 1994).

Warsaw Stock Exchange (WSE) due to the short history (WSE held its first trading session on April 16, 1991 with five listed companies, all of which were formerly State-owned companies that had been privatized) suffers from a low level of issuers' corporate governance and in consequence unsatisfactory of issuers from the WSE main market shows, that only $22 \%$ of companies explain the factors which are expected to have influential impact on the future performance of their brand and only $17 \%$ indicate the factors which can affect issuers' financial forecast. The report indicates the following reasons: the fear of responsibility and assumption that investors have enough knowledge about the branch characteristics and can by their own to interpret and analyse financial data on their own (Biernacki 2013). The situation on the alternative investment market NewConnect (NC) is even worse. The authors have conducted many interviews with NC issuers, nominated advisors and investors. While investors list the lack of voluntary information in quarterly and annual reports as the reason of limited interest in investing on the $\mathrm{NC}$, other parties believe that additional data and explanation disclosed expose issuers to the greater investors' activity in the direct contacting (phone calls and mails), what is not perceived as a positive phenomenon. The nominated advisors affirm that they discourage issuers from disclosing more information than it is required by the regulation.

The DQ is the issue studied by many researchers, however but the investigations are mostly focused on the issuers from regulated markets. In the articles, the authors mainly concentrate on the following relations: DQ and the cost of equity (Botosan 1997, Botosan, Plumlee 2002, Diamond, Verrecchia 1991, Lambert, Leuz, Verrecchia 2007, Sengputa 1998), DQ and firms' financial characteristics (Eng, Mak 2003, Healy, Hutton, Palepu 1999, Mallin, Ow - Yong 2009), DQ and corporate governance (Beekes, Brown 2006, Bushman, Smith 2001). Despite the fact that alternative investment markets (AIMs) have growing significance on the European financial markets there is a lack of publications analysing DQ of AIMs issuers and its relations with the firms' characteristics (the only available articles are Mallin, Ow - Yong 2009 and Fijałkowska et al. 2011).

The scope of our research is to examine relationship between disclosure quality and firms' characteristics of issuers listed on the Polish alternative investment market NewConnect. 


\section{NEWCONNECT - MARKET CHARACTERISTICS}

NewConnect, organized and operated by Warsaw Stock Exchange, started in late August, 2007. It is the fastest growing alternative investment market of 10 AIM operating in the European Union, when the number of issuers is analysed. 6 years after the opening, the number of companies listed on the market was 446, beating all markets except the London AIM. Since 2008 (the $2^{\text {nd }}$ year) the number of IPOs on the Polish AIM has far exceeded the number of IPOs on regulated market, as shown in Table 1.

Fast growth of alternative investment markets is caused by the increasing internationalization of financial markets and the high level of competition among stock exchanges in attracting companies and investors. To gain popularity with smaller companies, all most important stock markets decided to create a special segment which in comparison with the regulated markets is characterized by: lower barriers to entry, a faster admittance procedure, lower information requirements and (in most countries) creation of a network of advisory bodies (authorized advisers), cooperating with the stock exchanges when searching for new companies and engaged in advising companies on investor relations. Secondary market for shares of these companies is typically characterized by low liquidity (wide spread) and high volatility in transactions.

Nominated advisers usually develop the network of contacts with institutional and individual investors and advise many companies at the same time. This leads to the decentralization of the financial markets, so far centered around stock exchanges and a small group of brokerage houses. Nominated advisers (AD) are evaluated for their activity in popularizing the alternative market as a place to raise capital. An important element of the assessment is the number of companies for which the $\mathrm{AD}$ acquired capital, which may in some cases lead to a conflict of interest, in order to meet short-term requirements.

NewConnect, as an alternative investment market, is a place to raise capital primarily by firms with small market value (small shareholder funds). The vast majority would not comply with the minimum capitalization requirement on regulated stock market. Despite small capitalization and generally low liquidity (low free float and low turnover value), investors buy stocks in new issues (in private placements) and firms avoid a costly process associated with preparation and approval of the prospectus and IPO.

On the alternative market, firms are supported by the so called nominated advisers whose job is to make the selection of companies which want to list their shares on NewConnect. Then, they assist the company and help raise capital in private placements, prepare an information document (the equivalent of a prospectus on the regulated market), register the shares in the Central Securities Depository of Poland and enter the market. They also support the company in meeting its disclosure obligations.
On the basis of information gathered from information documents (the equivalent of prospectus on regulated market) of companies debuting on NewConnect in 2007-2011, we have tried to emphasize the main characteristics:

- the number of investors who participated in private placements usually ranged from 10 to 20 (33.6\% of companies), and in $77 \%$ of debutants from the period 2007 to 2011, the number of investors buying stocks in private placement did not exceed 29 , with an average of 21 , but the average number of the first investors has increased from an average of 9 (2007) to 22 (2011); in accordance with the existing regulations in Poland, a private placement can be offered to 99 investors;

- the median of companies' age was 5 years, i.e. half of the companies entering the market were five years old or younger and almost $18 \%$ of companies had a history of less than two years and can be classified as start-ups;

- raised capital in the new issues averaged 3.2 million PLN, but half of the emissions did not exceed 1.5 million PLN (median),

- Nominated Advisers (nomads) bought shares in about one third of all issues,

- in about $49 \%$ of companies, there were financial institutions under the shareholders, often they were investment vehicles associated with the previous owners, or with nominated advisors, or relatively small venture capital funds with a short-term speculative attitude,

- $87 \%$ of the companies issued new shares at different increasing prices several times before getting listed on the NewConnect. The situation was explained by increased risk of investing in start-ups,

- the average free float of issuers at IPO (defined as the percentage of share capital investors with a package of less than $5 \%$ ) was $18.2 \%$, but half of the companies had the free float rate below $16 \%$,

- the management board members held shares in $63 \%$ of companies when they started to be listed on NewConnect and the board members had a majority of shares (over $50 \%$ ) in almost $24 \%$ of cases,

- in case of supervisory boards - no shares in their possession could be identified in $22.6 \%$ of the companies, but in $35 \%$ of companies there were dominating parts (over $50 \%$ ) in the hands of members of the supervisory boards,

- the presence of institutional investors was revealed in case of $53 \%$ of issuers, and institutional investors had a majority of shares in case of $16 \%$ of firms; there were no financial investors in 22,6\% companies, but controlling interest (over 50\%) was held by advisory boards members of $35 \%$ of companies.

The year 2011 was a record year in terms of new issuers - 172 companies made their debut on NewConnect. That year seems to be a breakthrough. In subsequent years, a lot of violations of the regulations and failures to comply with disclosure require-

\begin{tabular}{ccccccccc}
\hline & Year & $2013^{*}$ & 2012 & 2011 & 2010 & 2009 & 2008 & 2007 \\
\hline \multirow{2}{*}{$\begin{array}{c}\text { Regulated } \\
\text { market }\end{array}$} & New companies & 18 & 19 & 38 & 34 & 13 & 33 & 81 \\
\cline { 2 - 8 } & Return of index WIG (\%) & $16,70 \%$ & 26,24 & $-20,83$ & 18,77 & 46,85 & $-51,07$ & 10,39 \\
\cline { 2 - 8 } NewConnect & New companies & 39 & 89 & 172 & 86 & 26 & 61 & 24 \\
\cline { 2 - 8 } & \begin{tabular}{c} 
Return of index NC Index (\%) \\
\cline { 2 - 8 }
\end{tabular} & $\begin{array}{c}\text { Average number of investors taking } \\
\text { part in a private placement }\end{array}$ & bd & bd & 22 & 19 & 15 & 27 \\
\hline
\end{tabular}

*on 30th November, 2013.

Table 1. Characteristics of Polish stock exchange and Polish AIM NewConnect in 2007 - 2013

[Source: www.gpw.pl, www.newconnect.pl] 
ments were observed. It forced the Warsaw Stock Exchange as an organizer of the market to introduce stricter regulations. In 2012, there were more than 10 cases of firms changing the industry in which they operated, giving the following official reasons:

- the failure of a formula business in the current sector,

- the entry of a new investor from another industry,

- the creation of a group and the willingness to act as the fund VC / PE.

All these features contribute to the formation of excessive asymmetry of information among the boards of companies, majority investors and the so-called free float investors. This situation often leads to moral hazard at the expense of minority shareholders.

\section{LITERATURE REVIEW AND HYPOTHESIS}

The empirical research shows that bigger issuers are more likely to disclose a larger number of information. This relation may be explained by the fact that bigger companies employ more qualified financial and accounting specialists and more often have internal regulations which require the elaboration of more detailed reports (Camfferman and Cooke, 2002) what confirms the results obtained by: McNally et al. (1982), Cooke (1989), Firth (1979), Hossain et al. (1994), Eng, Mak (2003). In many cases smaller companies listed on the NC do not have their own accounts departments and commission outside entities to prepare the disclosures. In addition, empirical research shows that newly listed issuers are more likely to disclose more information to attract greater number of investors (Mallin, Ow - Yong, 2009). What is more, for the analysing period (year 2011) on the NC there was an obligation for the issuers to cooperate with Nominated Advisor for at least one year after IPO (from 2013 WSE changed this regulation to at least 3 years). We believe that presence of Nominated Advisor has positive influence on the DQ. Based on the literature study and NC issuers' observation we formulate our first and second hypothesis as:

\section{H1: There is a positive relation between disclosure quality and firm size.}

H2: There is a negative relation between disclosure quality and firm listed period.

Greater DQ can also reduce agency costs as it allows better control of decisions and actions undertaken in the companies. Directors (agents) should encourage disclosing more information especially, when there is an institutional investor as a shareholder (Both, Healy (1999), Bushee, Noe (2000), Birt et al. (2006), Barako et al. (2006)). Reduction of agency costs due to the better control of actions taking by board members is especially crucial for issuers with high debt level. However, Jensen (1986) claims, that the agency costs of debt are controlled through restrictive debt covenants in debt agreements rather than increased disclosure of information in annual reports (Jensen, 1986). Empirical research gives mix results. Eng and Mak (2003) show negative relation between DQ and laverage ratio (Eng, Mak 2003), where Malone et al. (1993), Bardbury (1992), Ahmed, Courtis (1999) and Baroko et al. (2006) proves opposite relations: significant positive relations between DQ and laverage ratio, but Hossain et al. (1994), Ahmed, Nichollas (1994), Wallace, Naser (1995) do not find any significant relation between these two variables. We suspect that issuers on the NC due to the high level of information asymmetry very often suffer from moral hazard problem and issuers with higher leverage ratio prefer to limit disclosing information and to mitigate the possibility of evaluating performance; our third hypothesis is formulated as follow:

\section{H3: There is a negative relation between disclosure qual- ity and leverage ratio.}

\section{RESEARCH METHODS}

\subsection{SAMPLE AND DATA COLLECTION}

To investigate the relationship among disclosure quality, firm size, firm listed period and leverage ratio on the WSE Alternative Investment Market, we adopt a sample of firms that published their annual report for the year 2011. An initial sample of 231 issuers with the highest return shares is drawn from the NewConnect Statistic Bulletin for the year 2011. We exclude 31 firms due to:

- the lack of annual report,

- the lack of complete firm' characteristics data.

Finally, we conduct our research on the data collected from 200 issuers.

For the analysis, the data is obtained from:

- firms' financial data - provider Notoria Service through ISI Emerging Markets Information Service,

- data about disclosure quality from annual reports for the year 2011 .

\subsection{STATISTICAL MODEL AND VARIABLE MEASUREMENT}

To investigate our hypotheses from Section 3, a cross-sectional regression is employed. Our dependent variable is the Disclosure Quality Index (DQI) based on the information disclosed in 2011 annual reports. The construction of the index is used as a tool to study the disclosure quality (Chow and WongBoren 1987, Firth 1984, Cooke 1992; Botosan 1997, Ali, Ahmed and Henry 2004, Coy and Dixon 2004, Hassan, Romilly, Giorgioni and Power 2009). We use the DQI as a proxy for the overall level of information voluntarily disclosed via other means (Botosan 1997).

We develop our checklist on the basis of the study of Eugster and Wagner (2011) with small modification to make it suitable for NC issuers. The checklist consists of 74 questions divided into 9 categories. Studying annual report of the issuer we put 1 if the answer is positive and 0 otherwise. To create unweighted Index we evaluate the quality of each category by dividing the sum of positive answers with numbers of questions. The DQI is the sum of each category quality.

Multiple regressions are performed to test research hypotheses. We use three explanatory variables highlighted in Section 2 (i.e. 1_Assets - natural logarithm of total assets value as issuer size, D_EBITDA - debt to EBITDA as leverage ratio and Time - number of years from the first day listening as firm listed period. In addition, we include the following variables (all values are collected for the end of 2011 fiscal year): ROA - return on assets, ROE - return on equity, DEBTMAR - debt ratio (total debt to total assets), 1_Revenue - natural logarithm of total revenue value.

\section{DATA ANALYSIS AND CONCLUSIONS}

The descriptive statistic shows that the level of disclosure quality for the analyzing firm sample is very low (Table 3 ). The mean and median for DQI respectively is 2.41 and 2.31 , what if divided by the maximum score for our DQI $=9$ gives $27 \%$ and $26 \%$ of voluntary information disclosed and is much lower than the results obtained in previous studies (the mean for DQ: $32 \%$ in Egypt, Soliman (2013), 37\% in Greece, Leventis and Weetman (2004), 43\% in Switzerland, Eugster and Wagner 2011). The result is consistence with our observation and we indicate as the main reason the low level of issuers' corporate governance 
what is characteristic for the first stage of market development: the issuers are still learning their disclosing obligations, investors in majority adopt passive behaviour and low significance of financial investors.

We run regression model trying to explain which of previously selected variables are related to disclosure quality of issuers from NewConnect. The only significant correlation is between DQ and firm size (Table 1), what confirms findings from previous research (Meek et al., 1995; Hossain et al., 1995; Camfferman and Cooke, 2002; Eng and Mak, 2003; and Wang et al., 2008 , Soliman 2013). In literature there are two main explanations for this relation. First, that bigger company have more qualified employees to prepare the greater quality reports (Camfferman and Cooke, 2002) and second, that bigger companies face greater agency costs because they require large volumes of external capital to finance their investments (Jensen and Meckling 1976). To decrease the level of agency costs and to reinforce confidence they voluntary disclose a larger number of information (Marston and Polei 2004). We claim that in case of NC the first explanation is more adequate. Due to our estimation the average level on employment among NC companies is close to 50 employees, which means that many of NC issuers are very small entities without qualified management and outsource bookkeeping.

The regression model finds no support to hypothesis 2 and 3. We can observe negative correlation between debt to EBITDA ratio and DQ but it is not significant. Our findings support the low level of investor relation on the NC. In general issuers are not willing to help investors understand the reasons of performance and refuse to give a complex picture of companies' goals, strategic success factors, plan of future investments and risk management particulars.

\section{REFERENCES}

Ahmed, K., Courtis, J. K. Associations between corporate characteristics and disclosure levels in annual reports: a meta-analysis. British Accounting Review, 31(1), 35-61. (1999).

Ahmed, K., Nicholls, D. The impact of non-financial company characteristics on mandatory disclosure compliance in developing countries: the case of Bangladesh. The International Journal of Accounting, 29, 62-77. (1994).

Allegrini M., Greco M., Corporate boards, audit committees and voluntary disclosure: evidence from Italian Listed Companies, Journal of Management and Governance, Volume 17, pp 187216, February 2013

Barako, D. G., Hancock, P., Izan, H. Y., Factors influencing voluntary corporate disclosure by Kenyan companies. Corporate Governance: An International Review, 14,107 - 125, (2006)

Barry C., Brown S. Differential Information and Security Market Equilibrium. Journal of Financial and Quantitative Analysis 407-22. (December 1985)

Barry, C., Brown S. Differential information and the small firm effect. The Journal of Financial Economics 13: 283-294, 1984.

Beekes W., Brown P., Do better governed Australian firms make more informative disclosures? Journal of Business Finance \& Accounting 33, 422-450, (2006)

Biernacki P., Niedoceniane relacje inwestorskie, eBiuletyn NewConnect, 23/2013

Birt J. L., Bilson C. M., Smith T., Whaley R. E. Ownership, competition and financial disclosure. Australian Journal of Management, 31,235-263. (2006)

Blue Ribbon Report. Report and recommendations of the blue ribbon committee on improving the effectiveness of corporate audit committees. New York: New York Stock Exchange and the National Association of Securities Dealers, (1999).

Botosan, Ch. A., Disclosure Level and the Cost of Capital. The Accounting Review, Vol 72, No 3, July 1997, SSRN: http://ssrn. com/abstract $=2926$

Botosan, Ch. A., Plumlee, M. A., Assessing the Construct Validity of Alternative Proxies for Expected Cost of Equity Capital (April 2002), SSRN: http://ssrn.com/abstract $=310181$ or doi:10.2139/ ssrn. 310181
Bushee B., Noe Ch., Corporate Disclosure Practices, Institutional Investors, and Stock Return Volatility, Journal of Accounting Research, 171-202, (2000)

Bushee B., Noe Ch., Corporate Disclosure Practices, Institutional Investors, and Stock Return Volatility, Journal of Accounting Research, 171-202, (2000)

Bushman R., Smith A., Financial Accounting Information and Corporate Governance Journal of Accounting and Economics 31237-333, (2001)

Bushman R., Smith A., Financial Accounting Information and Corporate Governance Journal of Accounting and Economics 31237-333, (2001)

Cadbury Committee Report. Report of the Cadbury committee on the financial aspects of corporate governance. London: Gee, (1992).

Camfferman, K., Cooke, T. E. An Analysis of Disclosure in the Annual Reports of U.K. and Dutch Companies. Journal of International Accounting Research, 2002

Cooke, T.E. The impact of size, stock market listing and industry type on disclosure in the annual reports of Japanese listed corporations. Accounting and Business Research, 22 (87), 229237. (1992).

Diamond D.W., Verrecchia R.E., Disclosure, Liquidity, and the Cost of Capital, The Journal of Finance Volume 46, Issue 4, pp. 1325-1359, September 1991

Eng L.L., Mak Y.T. Corporate governance and voluntary disclosure, Journal of Accounting and Public Policy 22 (2003)

Eugster F., Wagner A., When and How is Voluntary Disclosure Quality Reflected in Equity Prices?, Swiss Finance Institute Research Paper Series 07/2011; DOI:10.2139/ssrn.1879804, 2011

Fijałkowska D., Muszyński M., Pauka M., Analiza jakości sprawozdań okresowych spółek notowanych na NewConnect, Prace i Materiały Wydziału Zarządzania Uniwersytetu Gdańskiego 2011, nr 2/1,343-352, 2011

Firth, M. The impact of size, stock market listing and auditors on voluntary disclosure in corporate annual reports. Accounting and Business Research, (Autumn),273-280. (1979).

Glosten L.R., Milgrom P.R. Bid, ask and transaction prices in a specialist market with heterogeneously informed traders, Journal of Financial Economics 14, 1985

Hassan, O.A.G., Romilly, P., Giorgioni, G., Power, D. The value relevance of disclosure: Evidence from the emerging capital market of Egypt. The International Journal of Accounting, 44(1), 79-102. (2009).

Healy, P., A. Hutton, K. Palepu. Stock Performance and Intermediation Changes Surrounding Sustained Increases in Disclosure. Contemporary Accounting Research (Fall): 485-520. 1999

Hossain, M., Perera, M., Rahman, A. Voluntary disclosure in the annual reports of New Zealand companies. Journal of International Financial Management and Accounting, 6(1), 69-85. (1995).

Jensen, M., Meckling, W. , Theory of the firm: managerial behavior, agency costs and ownership structure", Journal of Financial Economics 3, 305-360. (1976),

Jensen, M.C., Agency costs of free cash flow, corporate finance, and takeovers. American Economic Review 76, 323-329, 1986

Kim, O., Verrecchia R.E., Market liquidity and volume around earnings announcements. Journal of Accounting and Economics, 17 (January): 41-68, 1994

Lang, M.H., Lundholm R. Cross-sectional determinants of analyst ratings of corporate disclosures, Journal of Accounting Research 31 (Autumn): 246-71, 1993

Leventis, S., Weetman, P., Voluntary disclosures in an emerging capital market: Some evidence from the Athens Stock Exchange, Advances in International Accounting 17, 227-25. (2004)

Mallin Ch., Ow - Yong K. Corporate Governance in Alternative Investment Market (AIM) Companies: Determinants of Corporate Governance Disclosure, Presenter of paper at the Third Singapore International Conference on Finance 2009, http:// ssrn.com/abstract $=1326627$

Malone, D., Fries, C., Jones, T., An Empirical Investigation of the Extent of Corporate Financial Disclosure in the Oil and Gas Industry, Journal of Accounting and Finance 8 (3), 249-273. (1993), 
Marston, C., Polei, A. Corporate reporting on the Internet by German companies, International Journal of Accounting Information Systems 5 (3), 285 - 311. (2004)

McNally, G., Eng, L. H., Hasseldine, C. R, Corporate Financial Reporting in New Zealand: An Analysis of User Preferences, Corporate Characteristics and Disclosure Practices for Discretionary Information, Accounting and Business Research(Winter), 11-20. . (1982).

Merto, R.C. A simple model of capital market equilibrium with incomplete information. The Journal of Finance. (July): 483-510, 1987

\section{APPENDIX}

\begin{tabular}{cc}
\hline Variable & DQIs \\
\hline const & $1.31585^{\star *}$ \\
\hline l_Assets & $0.118514^{* *}$ \\
\hline D_EBITDA & $-0.00937005^{\star *}$ \\
\hline & \\
\hline $\mathrm{n}$ & 200 \\
\hline R-squared & 0.036299 \\
\hline P-value(F) & 0.026201 \\
\hline
\end{tabular}

Table 2. Regression model

\begin{tabular}{cccc}
\hline Variable & Mean & Median & Std. Dev. \\
\hline Time & 1.07500 & 1.00000 & 1.38889 \\
\hline DQIs & 2.40593 & 2.30992 & 1.00444 \\
\hline ROA_2011 & 0.00880414 & 0.0321148 & 0.225731 \\
\hline ROE_2011 & 0.0298960 & 0.0647078 & 0.327515 \\
\hline DEBTMAR_2011 & 0.430560 & 0.427306 & 0.357724 \\
\hline D_EBITDA_2011 & 2.26135 & 1.86922 & 15.0197 \\
\hline 1_Revenue2011 & 8.73402 & 8.95513 & 1.97753 \\
\hline 1_Assets_2011 & 9.37671 & 9.29837 & 1.31275 \\
\hline
\end{tabular}

Table 3. Summary Statistics, using the observations 1 - 200
OECD Principles of Corporate Governance. (1999)

Sengupta, P. Corporate disclosure quality and the cost of debt. The Accounting Review 73:459-474. 1998.

Soliman M.M., Firm Characteristics and the Extent of Voluntary Disclosure: The Case of Egypt, Research Journal of Finance and Accounting, Vol.4, No.17, 2013

Verrecchia, R. E. Discretionary Disclosure. Journal of Accounting \& Economics 5: 179-194. 1983.

Verrecchia, R. E. Essays on Disclosure. Journal of Accounting \& Economics 32: 97-180. 2001.

Verrecchia, R. E. Information Quality and Discretionary Disclosure. Journal of Accounting \& Economics 4: 365-381. 1990.

Wallace, R., Naser, K., Firm specific determinants of the comprehensiveness of mandatory disclosure in the corporate annual reports of firms listed on the stock exchange of Hong Kong, Journal of Accounting and Public Policy 14, 311-368. (1995),

Welker, M. "Disclosure Policy, Information Asymmetry, and Liquidity in Equity Markets." Contemporary Accounting Research 11, 801-827, (1995)

\begin{tabular}{|c|c|c|c|c|c|c|c|c|}
\hline$\underset{\Xi}{\Xi}$ & $\begin{array}{l}\ddot{a} \\
\ddot{a}\end{array}$ & 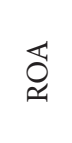 & 띵 & 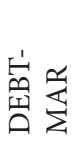 & 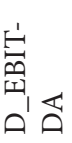 & 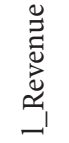 & 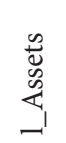 & \\
\hline \multirow[t]{8}{*}{1.00} & 0.09 & 0.04 & 0.05 & 0.06 & -0.01 & 0.05 & 0.02 & Time \\
\hline & 1.00 & -0.01 & -0.05 & 0.01 & -0.11 & 0.16 & 0.13 & DQIs \\
\hline & & 1.00 & 0.70 & -0.17 & 0.02 & 0.22 & 0.13 & ROA \\
\hline & & & 1.00 & -0.10 & 0.09 & 0.22 & 0.10 & ROE \\
\hline & & & & 1.00 & 0.14 & 0.28 & 0.12 & DEBTMAR \\
\hline & & & & & 1.00 & 0.01 & 0.17 & D_EBITDA \\
\hline & & & & & & 1.00 & 0.53 & 1_Revenue \\
\hline & & & & & & & 1.00 & 1_Assets \\
\hline
\end{tabular}

Table 4. Correlation analysis

Model 1: OLS, using observations 1-200

Dependent variable: DQI

\begin{tabular}{lccccl}
\hline & Coefficient & Std. Error & t-ratio & p-value & \\
\hline const & 0.146205 & 0.0569127 & 2.5689 & 0.01094 & ${ }^{* *}$ \\
\hline l_Assets_2011 & 0.0131682 & 0.00603267 & 2.1828 & 0.03023 & ${ }^{* *}$ \\
\hline D_EBITDA_2011 & -0.00104112 & 0.000527265 & -1.9746 & 0.04972 & ${ }^{* *}$ \\
\hline
\end{tabular}

\begin{tabular}{llll}
\hline Mean dependent var & 0.267326 & S.D. dependent var & 0.111604 \\
\hline Sum squared resid & 2.388663 & S.E. of regression & 0.110114 \\
\hline R-squared & 0.036299 & Adjusted R-squared & 0.026515 \\
\hline F(2, 197) & 3.710136 & P-value(F) & 0.026201 \\
\hline Log-likelihood & 158.9706 & Akaike criterion & -311.9413 \\
\hline Schwarz criterion & -302.0463 & Hannan-Quinn & -307.9369 \\
\hline
\end{tabular}

\section{KVALITET OBELODANJIVANJA NA NEWCONNECT ALTERNATIVNOJ PLATFORMI ZA TRGOVANJE NA VARŠAVSKOJ BERZI}

Dominika Fijałkowska ${ }^{1}$, Michał Muszyński, Marek Pauka

${ }^{1}$ Faculty of Economic Sciences, Wroclaw University of Economics, Komandorska 118/120, Wroclaw, Poland, fijalkowska.dominika@gmail.com

\section{Apstrakt:}

Ovo istraživanje usmereno je ka ispitivanju odnosa između kvaliteta obelodanjivanja i karakteristika preduzeća emitenata na NewConnect alternativnoj platformi za trgovinu na Varšavskoj berzi. Ispitivanjem uzorka od 200 emitenata ustanovljeno je da je kvalitet obelodanjivanja u značajnoj i pozitivnoj korelaciji sa veličinom preduzeća kao i da ne postoji dokaz o odnosu između kvaliteta obelodanjivanja, koeficienta dugovanja i istorije poslovanja emitenata. Emitenti nisu voljni da obrazlože investitorima razloge za takav učinak i odbijaju da pruže kompleksnu sliku ciljeva kompanije, strateških faktora uspeha, investicionih planova i pojednosti vezanih za upravljanje rizikom. Rezultati su dosledni sa našim opažanjima i ukazuju na nizak nivo korporativnog upravljanja, što je uobičajeno za prvu fazu razvoja tržišta: emitenti se i dalje upoznaju sa obavezama vezanim za obelodanjivanje, investitori usvajaju pasivno ponašanje, a finansijski investitori imaju neznatan značaj kao učesnici na tržištu.

\section{Ključne reči:}

dobrovoljno obelodanjivanje, godišnji izveštaj, učinak preduzeća, alternativno investiciono tržište. 